$$
\begin{aligned}
& \text { 高速双ロールキャスタにより作製した } \\
& \text { 鉄量の多い } 6022 \text { アルミニウム合金板の機械的性質 } \\
& \begin{array}{r}
\text { 徳田 健二 }{ }^{* * * * *} \text {. 熊井 真次 } * * * \text {. 鈴木 健太 } * * * * * \\
\text { 石原 暁子 } * * * * * \text {. 羽賀 俊雄 } * * * * * *
\end{array}
\end{aligned}
$$

Journal of Japan Institute of Light Metals, Vol. 57, No. 10 (2007), pp. 444-449

\title{
Mechanical properties of 6022 aluminum alloy sheets with high iron content fabricated by a high-speed twin-roll caster
}

\author{
Kenji TOKUDA $^{*, * *}$, Shinji KUMAI***, Kenta SUZUKI**** \\ Akiko ISHIHARA ${ }^{* * * * * *}$ and Toshio HAGA ${ }^{* * * * * * *}$
}

\begin{abstract}
Influence of iron content $(0.2-1.0$ mass $\%)$ and solidification rates $\left(3-1200^{\circ} \mathrm{C} / \mathrm{s}\right)$ during casting on mechanical properties of 6022 base aluminum alloys were investigated. Molten alloys were cast into about $3 \mathrm{~mm}$ thick plate by a vertical-type high-speed twin-roll caster (HSTRC). Conventional book-type mold casting with a thickness of $5 \mathrm{~mm}$ and $50 \mathrm{~mm}$ were also fabricated for a purpose of comparison. The castings were rolled into $1 \mathrm{~mm}$-thick sheets and then heat-treated. Iron content had a small effect on tensile strength of the sheet for both T4 temper and after baking-treated conditions. While, elongation decreased with increasing iron content. Solidification rates also had a small effect on the strength, though HSTRC sheet exhibited a little higher strength. This is considered to be due to higher solute content in the Al matrix of the rapidly solidified HSTRC product. Bendability was also deteriorated with the increase of iron content. It was remarkable for the sheet produced from the $50 \mathrm{~mm}$-thick plate with the low solidification rate. Improved bendability of the sheets fabricated from high solidification rate products (HSTRC and $5 \mathrm{~mm}$-thick plate) was considered to be mainly due to the finer second phase particles.
\end{abstract}

(Received March 14, 2007 Accepted June 8, 2007)

Keywords: twin-roll cast, 6022 aluminum alloy, cooling rate, mechanical property

\section{1. 緒言}

近年，自動車パネルなどへの 6000 系アルミニウム合金板 の適用が進展しており，今後も更に拡大していくことが期待 されている。使用量の増加に伴い， スクラップの有効活用が 不可欠となるが， 6000 系アルミニウム合金はスクラップ中の 代表的な不純物である鉄を多く含むと成形性や曲げ性などの 機械的性質が低下することが知られている(1),2)。特性低下の 原因としては粗大な第 2 相粒子の影響が大きいとされており, 急冷凝固が可能となる双ロール鋳造法を代表とする薄板連鋳 プロセスを活用し，第 2 相粒子の微細化による鉄の無害化が 検討されている3),4)。

Haga らは従来の横型双ロールキャスタの一つの欠点である 低い生産性（鋳造速度：1 $\mathrm{m}$ 前後/分）を克服することが可能 な高速双ロールキャス夕を開発してきている5),6)。高速双ロー
ルキャスタでは従来の 10 100 倍の速度（鋳造速度：最大 $150 \mathrm{~m} /$ 分）での鋳造が可能であり，凝固時の冷却速度む 10 倍 前後となることが確認されており, 生産性の大幅な向上に加 えて，鉄などの不純物元素の許容量拡大が期待される。 Suzuki らは高速双ロールキャス夕を用いて 6063 合金をベース として鉄含有量の影響を調査し，鉄含有量 $0.7 \%$ までは特性 が低下しないことを確認している ${ }^{6)}$ 。本研究では，代表的な 自動車パネル用合金である 6022 合金をべースとして鉄含有 量と凝固速度の影響を調査し，高速双ロールキャス夕による 特性改善の可能性を検証した。

\section{2. 実 験方法}

6022 合金をベースとし，鉄を添加することにより鉄含有量 0.2, 0.4, 0.6, 0.8, 1.0 mass\% の 5 種類の合金を作製した。Table 1 に作製した合金の化学組成を示す。それぞれの合金を高速

*東京工業大学大学院生（７ 226-8502 神奈川県横浜市緑区長津田町 4259)。Graduate student, Tokyo Institute of Technology (4259 Nagatsuda, Midori-ku, Yokohama-shi, Kanagawa 226-8502).

** (株)神戸製鋼所真岡製造所アルミ板研究部（真岡市)。Aluminum Sheets \& Coils Research Department, Moka Plant, KOBE STEEL Ltd. (Moka-shi, Tochigi).

**** 東京工業大学（横浜市)。Department of Materials Science and Engineering, Tokyo Institute of Technology (Yokohama-shi, Kanagawa).

*****東京工業大学（横浜市）〔現在：日本軽金属(森)（静岡市)〕。Department of Materials Science and Engineering, Tokyo Institute of Technology [Present: Nippon Light Metal Co., Ltd. (Shizuoka-shi, Shizuoka)).

******東京工業大学大学院生（横浜市）〔現在：日産自動車(株)。Graduate student, Tokyo Institute of Technology [Present: Nissan Motor Co., Ltd.].

********大阪工業大学（大阪市）。Department of Mechanical Engineering, Osaka Institute of Technology (Osaka-shi, Osaka). 
Table 1 Chemical composition (mass\%) of alloys used in this study

\begin{tabular}{c|c|c|c|c|c|c}
\hline \hline Element & $\mathrm{Fe}$ & $\mathrm{Si}$ & $\mathrm{Mn}$ & $\mathrm{Mg}$ & $\mathrm{Ti}$ & $\mathrm{Al}$ \\
\hline $0.2 \% \mathrm{Fe}$ & 0.2 & 1.0 & 0.1 & 0.6 & 0.02 & $\mathrm{Bal}$. \\
$0.4 \% \mathrm{Fe}$ & 0.4 & 1.0 & 0.1 & 0.6 & 0.02 & $\mathrm{Bal}$. \\
$0.6 \% \mathrm{Fe}$ & 0.6 & 1.0 & 0.1 & 0.6 & 0.02 & $\mathrm{Bal}$. \\
$0.8 \% \mathrm{Fe}$ & 0.8 & 1.0 & 0.1 & 0.6 & 0.02 & $\mathrm{Bal}$. \\
$1.0 \% \mathrm{Fe}$ & 1.0 & 1.0 & 0.1 & 0.6 & 0.02 & $\mathrm{Bal}$. \\
\hline
\end{tabular}

ロールキャスタと，鋳塊厚さ $5 \mathrm{~mm}$ と $50 \mathrm{~mm}$ の 2 種類のブッ クモールド（金型）を用いて，それぞれ 3 種類の鋳塊を作製 した。以降，それぞれの材料を HSTRC 材 (High-speed twinroll cast), t5 金型材 (t5 mold cast), t50 金型材 (t50 mold cast) と呼称する。本研究で用いた縦型の高速双ロールキャス夕は, ロールに水冷式の純銅ロールを使用するとともに，離型剂を 使用しないため, 板表面部で数千 ${ }^{\circ} \mathrm{C} / \mathrm{s}$ の高い冷却速度を得る ことができる。鋳造速度は $60 \mathrm{~m} / \mathrm{min}$, 鋳造温度は液相線温度 より約 $5^{\circ} \mathrm{C}$ 高い $660^{\circ} \mathrm{C}$, 凝固距離 : $100 \mathrm{~mm}$, ロール荷重 : $20 \mathrm{kN}$ ，メタルヘッド（ロール間の溶湯溜り深さのことであ り, ここでは凝固開始位置での溶湯溜り深さと定義する)： $0 \mathrm{~mm}$ とし，得られた鋳造板は幅 $100 \mathrm{~mm}$ ，板厚はおよそ $3 \mathrm{~mm}$ である。なお， 6022 合金の高速ロールキャスト材では，高い 冷却速度が得られる鋳造条件では板厚中央部に内部割れが発 生する場合があるため, 本研究では低メタルヘッドとし, 溶 湯静水圧を低減して冷却速度を抑制する条件で鋳造板を作製 している7)。

HSTRC 材と $\mathrm{t} 5$ 金型材は鋳造のまま, 一方, t50 金型材は鋳 塊厚中央部より $5 \mathrm{~mm}$ 厚さに切出したものを元材料として使 用した。試作工程のフローチャートを Fig. 1 に示す。約 $3 \mathrm{~mm}$ 厚 (HSTRC 材) と $5 \mathrm{~mm}$ 厚（t5 金型材と $\mathrm{t} 50$ 金型材）の鋳塊 は $550^{\circ} \mathrm{C}$ で 4 時間の均質化熱処理後に冷間圧延により $1 \mathrm{~mm}$ 厚とした。得られた板は塩浴炉にて $550^{\circ} \mathrm{C}, 30$ 秒の溶体化処 理を行い, 水冷後に $70^{\circ} \mathrm{C}, 2$ 時間の予備時効熱処理, 更に $40^{\circ} \mathrm{C}$ で 5 日間保持した後に $\mathrm{T} 4$ 調質の供試材とした（以降, $\mathrm{T} 4$ 材之呼称する)。なお，比較として均質化熱処理を省略し た工程でも T4 材を作製した。また，自動車外板パネル材と して使用される場合のプレス成形工程と塗装焼付け工程を想 定して， T4 材に $2 \%$ の引張予ひずみを付与した後に $170^{\circ} \mathrm{C}$, 20 分の焼なましを施してベークハード性の評価のための供試 材とした（以降， $\mathrm{AB}$ 材と呼称する）。得られた鋳塊について は光学顕微鏡観察, T4 材については光学顕微鏡観察之引張 試験，曲げ試験， $\mathrm{AB}$ 材については引張試験を実施した。

鋳塊組織観察は鋳造方向に対して垂直断面，T4 材の組織 観察は圧延平行断面とし，研磨のまま，または研磨後に $2 \%$ ふっ化水素酸水溶液にて電圧 $25 \mathrm{~V}, 90$ 秒の陽極酸化処理を施 して光学顕微鏡観察を行った。引張試験は圧延平行方向に JIS13B 引張試験片を採取し, インストロン型引張試験機を用 いて行った。曲げ試験は圧延平行方向に長さ $200 \mathrm{~mm}$, 幅 $30 \mathrm{~mm}$ に切出した板材に $10 \%$ 引張予ひずみを付与し，押曲げ 法（JIS Z2248）により内側曲げ半径 $0.5 \mathrm{~mm}$ の突押し後 180 度 密着曲げを実施した。

鋳塊の第 2 相粒子の形態は, 熱フェノール抽出後 ${ }^{8}$ に $\mathrm{SEM}$ 観察により行った。T4 材の第 2 相粒子の分布については, 圧 延平行断面を SEM 観察し, 得られた像の画像解析（測定面

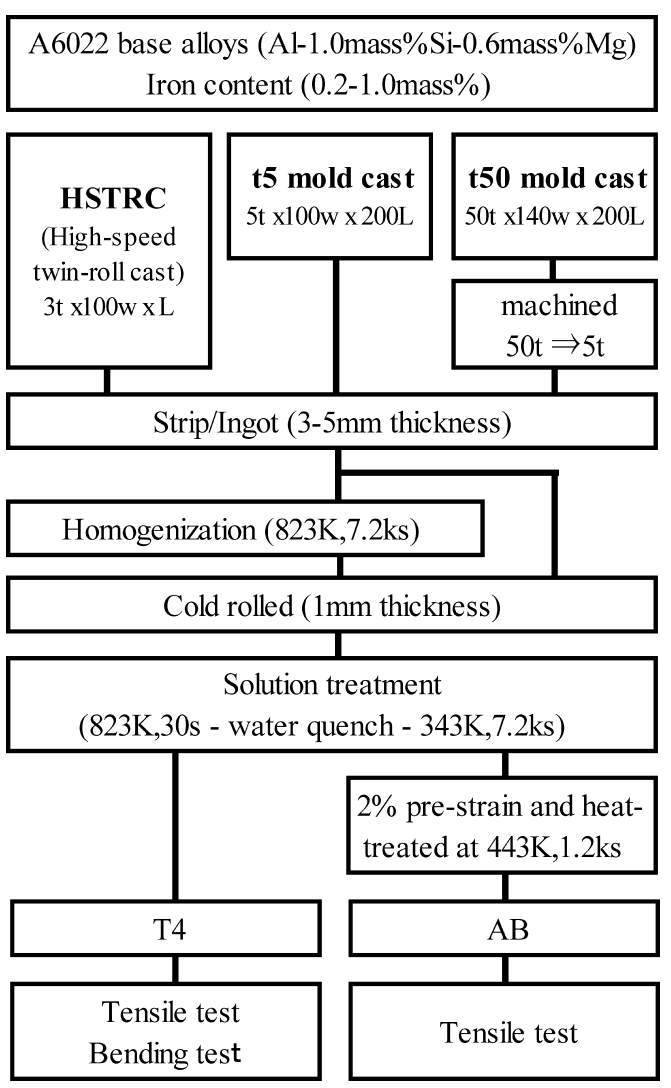

Fig. 1 Experimental procedure.

積： $1 \mathrm{~mm}^{2}$ ) により定量測定を行った。また, $\mathrm{T} 4$ 材の固溶状 態の評価は, 導電率測定, および熱フェノール抽出液の ICP 発光分析による固溶けい素量の分析を実施した。

\section{3. 実 験 結 果}

\section{1 鋳塊組織と冷却速度の推定}

Fig. 2 に $0.2 \% \mathrm{Fe}$ と $1.0 \% \mathrm{Fe}$ 合金のそれぞれの鋳塊表面近傍 の光顕組織観察結果例を示す。なお，HSTRC 材と $\mathrm{t} 5$ 金型材 の鋳塊表面は鋳造のままであるが, $\mathrm{t} 50$ 金型材では表面は機 械加工された面である。鋳塊組織は $\alpha$ - $\mathrm{Al}$ (明灰色) と $\mathrm{Al}-\mathrm{Fe}-$ $\mathrm{Si}$ 系の晶出物 (暗灰色) からなり（一部 $\mathrm{Mg}-\mathrm{Si}$ 系晶出物も含 まれる), HSTRC 材では鉄量が増加しても晶出物は非常に微 細であった。一方, t50 金型材では晶出物は粗大であり, 鉄 含有量が増加するほどその傾向は顕著であった。また, t5 金 型材は HSTRC 材と $\mathrm{t} 50$ 金型材の中間的な組織形態であった が，鉄量が増加しても晶出物は著しく粗大化することはな かった。

金型材については, 熱電対を用いて凝固時の温度測定を実 施し，冷却速度を算出した。t5 金型材と $\mathrm{t} 50$ 金型材の冷却速 度はそれぞれ $93^{\circ} \mathrm{C} / \mathrm{s}, 3.0^{\circ} \mathrm{C} / \mathrm{s}$ であり, それぞれ通常の横型ロー ルキャス夕と DC 鋳造とほぼ同等の冷却速度であった。なお， 温度測定のサンプリング周期は 0.1 秒, 測定位置は鋳塊厚中 央部とし, 冷却速度は凝固温度範囲における冷却速度加ら算 出した。Fig. 3 にそれぞれの鋳造材の冷却速度とDAS の関係 を示す。HSTRC 材では冷却速度の直接測定は困難であるた め, 金型材の冷却速度 (C) と DAS $(\mu \mathrm{m})$ （ t5 金型材と $\mathrm{t} 50$ 金型材の DAS はそれぞれ $18.3 \mu \mathrm{m}, 112 \mu \mathrm{m})$ の関係より導出 される式： $\mathrm{DAS}=66.7 \mathrm{C}^{-0.53}$ を用いて冷却速度を推定した。導 


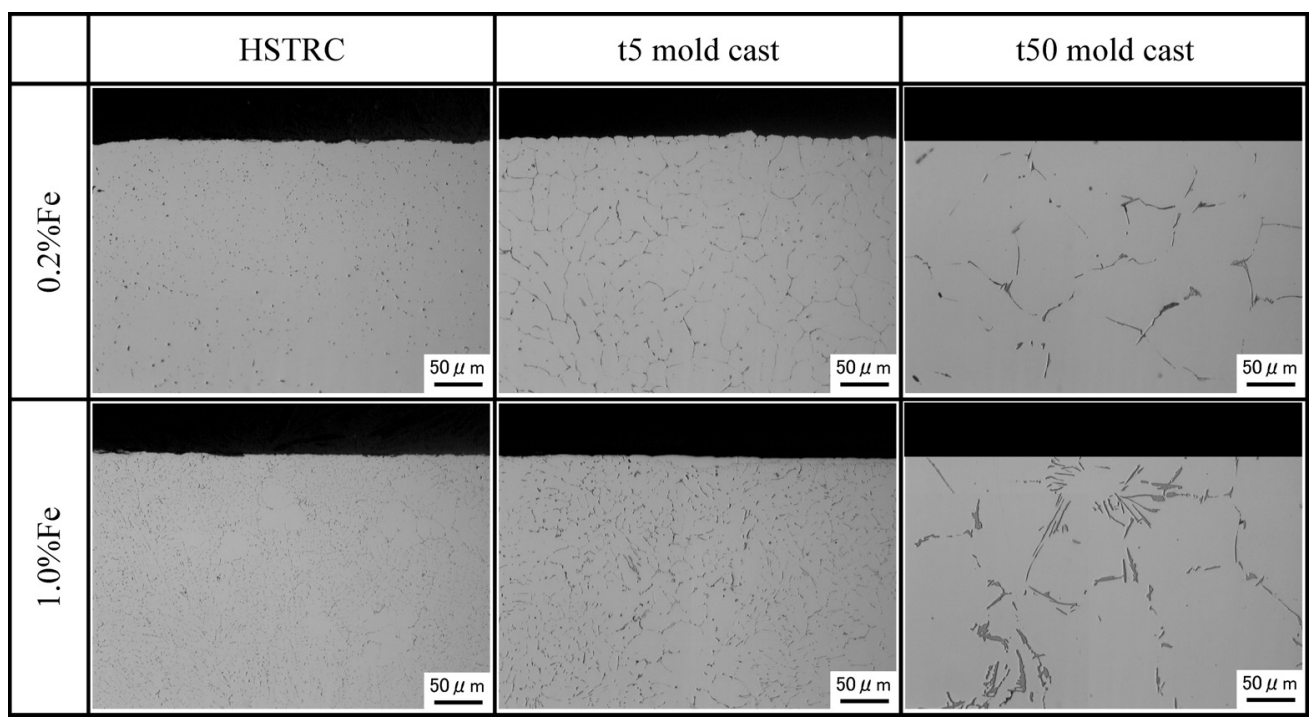

Fig. 2 Optical micrographs of cast plate.

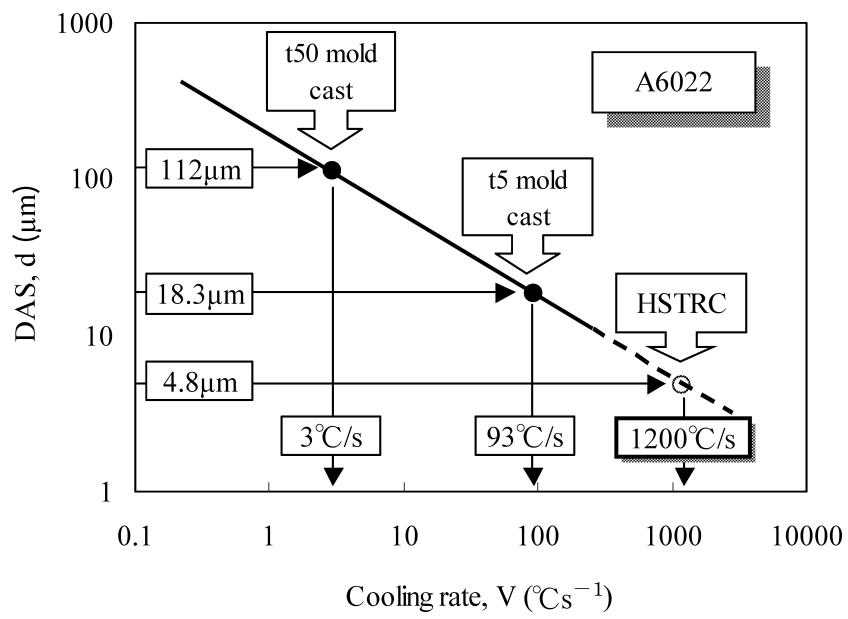

Fig. 3 Estimation of a cooling rate of HSTRC.

出式より得られた HSTRC 材の冷却速度は約 $1200^{\circ} \mathrm{C} / \mathrm{s}$ であり, t5 金型材の 10 倍以上の冷却速度であった。なお, 高速双 ロールキャストでは条件によっては $6000^{\circ} \mathrm{C} / \mathrm{s}$ 程度の冷却速度 が得られることがわかっているが7)，既述したように本研究 では鋳造割れ抑制のために冷却速度を低減する条件で作製し ており，鋳造機本来の急冷凝固能力を十分には発揮できてい ない。

\section{$3.2 \mathrm{~T} 4$ 材のミクロ組織}

Fig. 4 に $0.2 \% \mathrm{Fe}$ と $1.0 \% \mathrm{Fe}$ の $\mathrm{T} 4$ 材の板厚表面近傍のミク 口組織観察結果例を示す。結晶粒径は鉄量が多いほよ゙微細で あり， $0.2 \% \mathrm{Fe}$ 材では約 $40 \mu \mathrm{m}, 1.0 \%$ 材では $10 \sim 20 \mu \mathrm{m}$ であっ た。HSTRC 材と金型材では鉄量が少ない場合はほぼ同等の結 晶粒径であり，鉄量が多い場合は t50 金型材が他材料よりも やや粗大となる傾向であった。なお，HSTRC 材，金型材は鋳 塊からの加工率はそれぞれ約 $60 \%$, 約 $80 \%$ であるが， t50 金 型材では鋳塊の DAS が粗大であったため, 晶出物が層状に 分散した組織となっており, 均一分散に近い HSTRC 材と t5 金型材とは異なった分散状態であった。

\section{3 引張特性}

Fig. 5 に均質化熱処理ありの工程での $\mathrm{T} 4$ 材と $\mathrm{AB}$ 材の $0.2 \%$ 耐力, Fig. 6 に $\mathrm{T} 4$ 材の伸びを示す。 $\mathrm{T} 4$ 材の $0.2 \%$ 耐力 は鉄量と冷却速度によらずほぼ一定であり，130 140 MPa で
あった。一方, $\mathrm{AB}$ 材の $0.2 \%$ 耐力はいずれの冷却速度材でも 鉄量の影響はほとんどなかったが，冷却速度が大きいほど $0.2 \%$ 耐力はやや高い傾向にあり, 特に HSTRC 材で高い值を 示した。 $\mathrm{T} 4$ 材の伸びは冷却速度によらず，HSTRC 材と金型 材はほぼ同等であり, 鉄量の増加に伴い低下し， $0.2 \% \mathrm{Fe}$ で $25 \%$ 以上であったが， $1.0 \% \mathrm{Fe}$ では $20 \%$ 程度となった。

Fig. 7 に均質化熱処理なしの工程での $\mathrm{T} 4$ 材と $\mathrm{AB}$ 材の $0.2 \%$ 而力を示す。均質化熱処理ありの工程と同様に, 鉄量 の影響はほとんどなかった。冷却速度の影響については, T4 材では $\mathrm{t} 50$ 金型材が全体的に低く, HSTRC 材と $\mathrm{t} 5$ 金型材は 同等であった。一方, $\mathrm{AB}$ 材では冷却速度が大きいほど耐力 が高い傾向を示し，その差は均質化熱処理ありの工程よりも 顕著であった。

\section{4 曲げ性}

Fig. 8 に曲げ試験後の試験片の外観（上段）および断面観 察結果例（下段）を示す。鉄量が増加するに伴い，いずれの 材料でも曲げ性が低下した。50t 金型材では鉄量が $0.8 \%$ 以上 で亀裂が板厚全体を貫通しており，鉄量が多くなると HSTRC 材と 5 金型材よりも曲げ性が顕著に低下した。HSTRC 材と t5 金型材はいずれの鉄量でもほぼ同等の曲げ性を示した。ま た，均質化熱処理なしの工程では全体的に曲げ性が大きく低 下していた。なお，均質化熱処理なしの $\mathrm{T} 4$ 材耐力レベルは 冷却速度によって大きく変化しており, 曲げ性の直接比較が 困難であったため，結果の詳細については割愛する。

\section{4. 考察}

\section{1 引張特性に及ぼす鉄量と凝固時の冷却速度の影響}

引張特性に及ぼす鉄量と凝固時の冷却速度の影響として得 られた結果をまとめると以下となる。

a）強度に及ぼす鉄量の影響は小さく, $\mathrm{T} 4$ 材, $\mathrm{AB}$ 材とも に $1.0 \% \mathrm{Fe}$ 材でも $0.2 \% \mathrm{Fe}$ 材とほぼ同等の $0.2 \%$ 耐力が得られ た。ただし，伸びは鉄量の増加に伴い低下した。

b）凝固時の冷却速度が大きいほど $\mathrm{AB}$ 材の $0.2 \%$ 而力は高 く, 特に均質化熱処理なしの工程ではその傾向が顕著であっ た。

a）引張特性に及ぼす鉄量の影響

6000 系合金では鉄量の増加に伴い Al-Fe-Si 系の晶出物量 が増加するために固溶けい素量が減少し, 時効硬化能が低下 


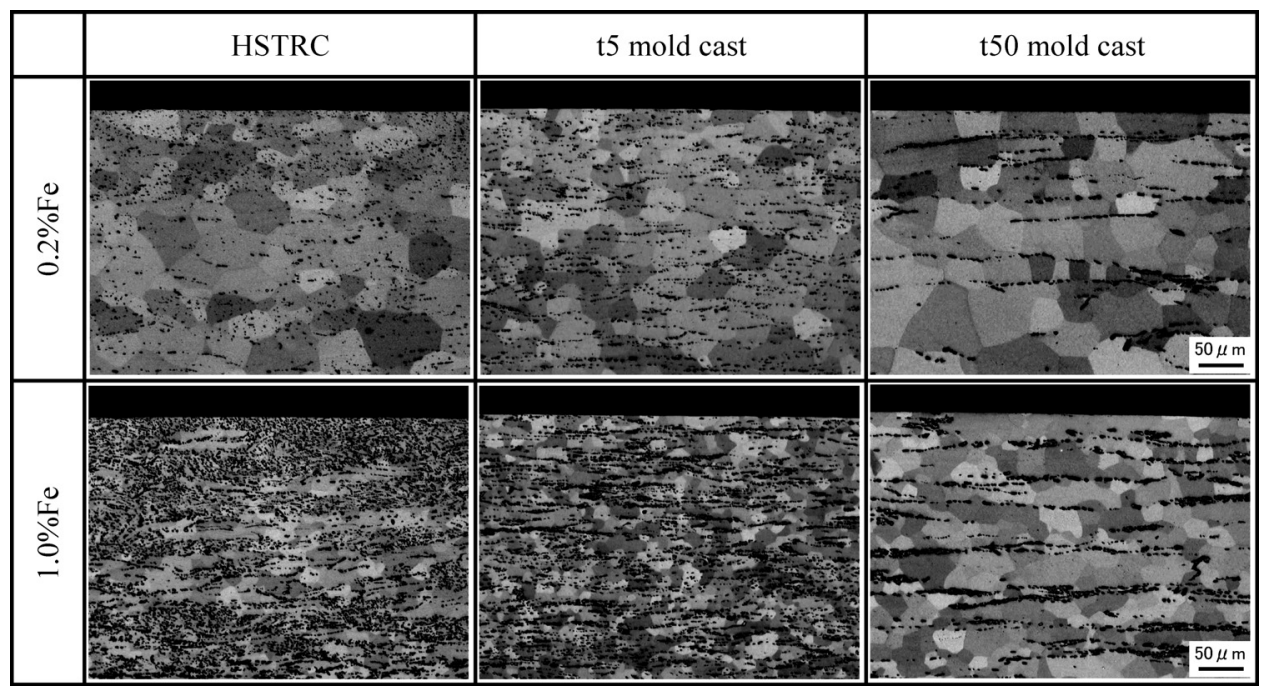

Fig. 4 Micro-structure of T4 sheets.

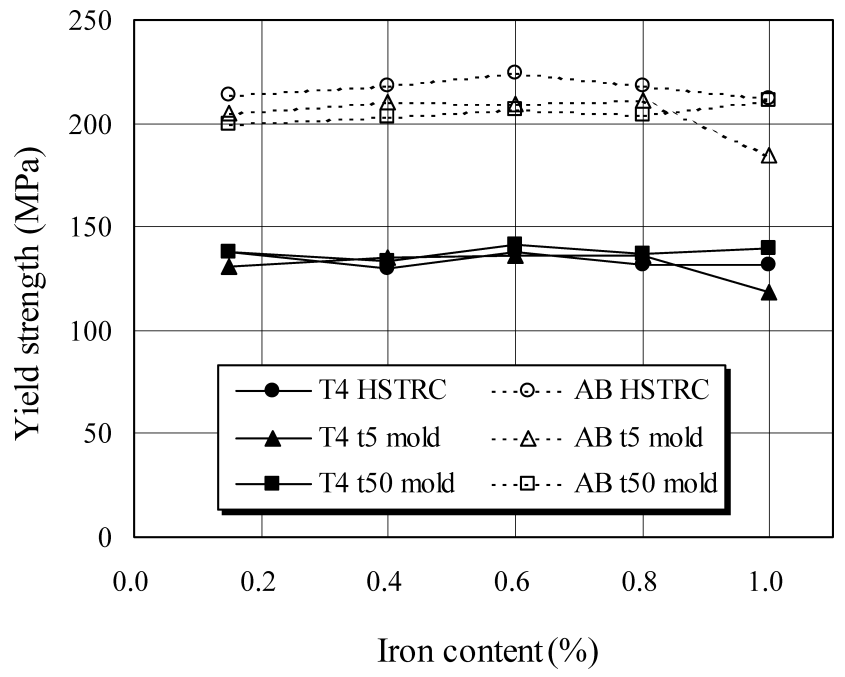

Fig. 5 Yield strength of $\mathrm{T} 4$ and $\mathrm{AB}$ sheets.

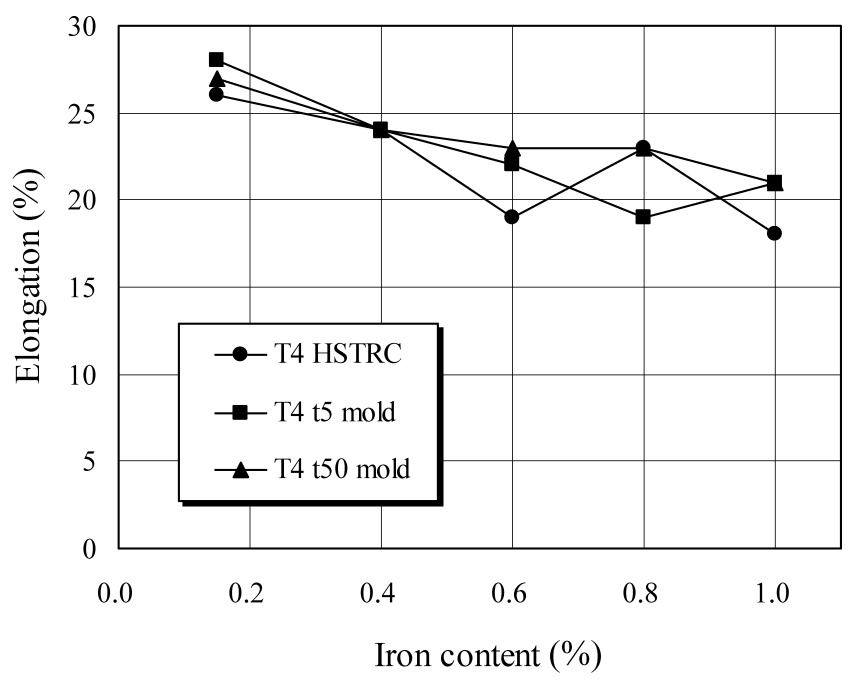

Fig. 6 Elongation of $\mathrm{T} 4$ sheets.

するとされている。特に過剩けい素量は時効初期の硬化速度 （ベークハード性）に影響を及ぼすことが知られており，鉄 量増加によりベークハード性が低下することが報告されてい る1)。本研究では鉄量増加に伴う $\mathrm{AB}$ 材の $0.2 \%$ 耐力の低下は ほとんどなく，これまでの報告とは異なる結果が得られてい

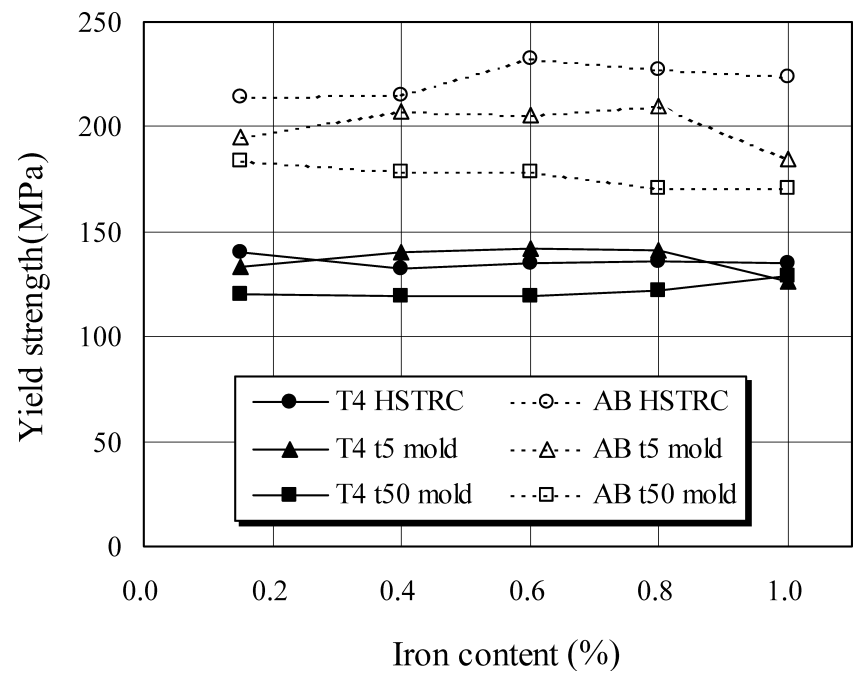

Fig. 7 Yield strength of $\mathrm{T} 4$ and $\mathrm{AB}$ sheets. (without homogenization process)

る。これは, 合金成分や均質化熱処理, 溶体化熱処理などの 試作条件の違い, 更にはベーキング処理などの評価条件の違 いによるものであると思われるが，少なくとも本研究による 結果では, $1.0 \%$ 程度までの鉄量であれば延性は低下するもの の, 自動車外板用などで重要となるべークハード性はほとん ど低下しなかった。

そこで，T4 材の固溶状態の評価を目的として，固溶けい 素量の分析と導電率測定を実施した。まず, 固溶けい素量に ついては, 冷却速度の影響はほとんどなく, $0.2 \% \mathrm{Fe}$ 材で $0.8 \sim 0.9 \%$ 程度, $1.0 \% \mathrm{Fe}$ 材で $0.55 \%$ 前後の值が得られた。固 溶けい素量の差は, $\mathrm{Al}-\mathrm{Fe}-\mathrm{Si}$ 系晶出物 $\left\{\alpha-\mathrm{AlFeSi}\left(\mathrm{Fe}_{2} \mathrm{SiAl}_{8}\right.\right.$ ま たは $\left.\mathrm{Fe}_{3} \mathrm{Si}_{2} \mathrm{Al}_{12}\right)$ ，または $\beta$ - $\left.\mathrm{AlFeSi}\left(\mathrm{FeSiAl}_{5}\right)\right\}$ 中に取込まれる と推定されるけい素量 $\left(0.25 \%\right.$ 以上 $\left.{ }^{1), 9)}\right)$ にほぼ対応してお り，1.0\% Fe 材では晶出物中に取込まれる分だけ固溶けい素量 が減少していると考えられる。

一方, T4 材の導電率測定結果を Fig. 9 に示す。一部例外 はあるものの，全般的にいずれの冷却速度でも鉄量の増加に 伴い導電率は高くなる傾向を示しており， $0.2 \% \mathrm{Fe}$ 材と $1.0 \%$ $\mathrm{Fe}$ 材の導電率差は平均で $1 \%$ 程度, 最大でも $2 \%$ 以下であっ た。固溶けい素の導電率へ寄与量は $17.1 \mathrm{IACS} \% / \mathrm{mass} \%$ とさ れている ${ }^{10)}$ 。熱フェノール分析結果に基づくと, $1.0 \% \mathrm{Fe}$ 材 


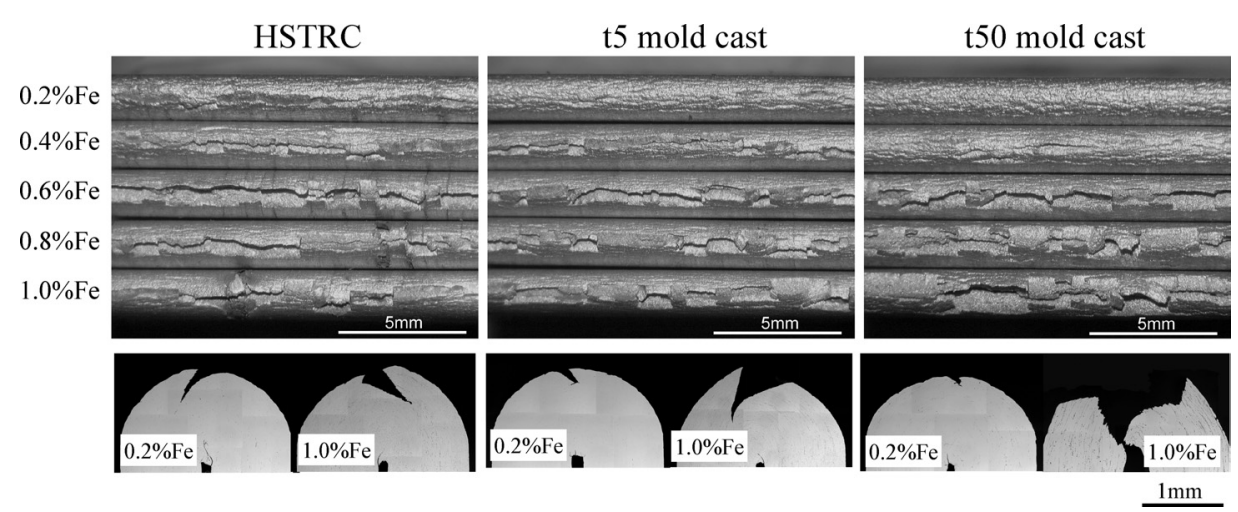

Fig. 8 Appearances of specimen surface (upper) and cross section (lower) after bending test.
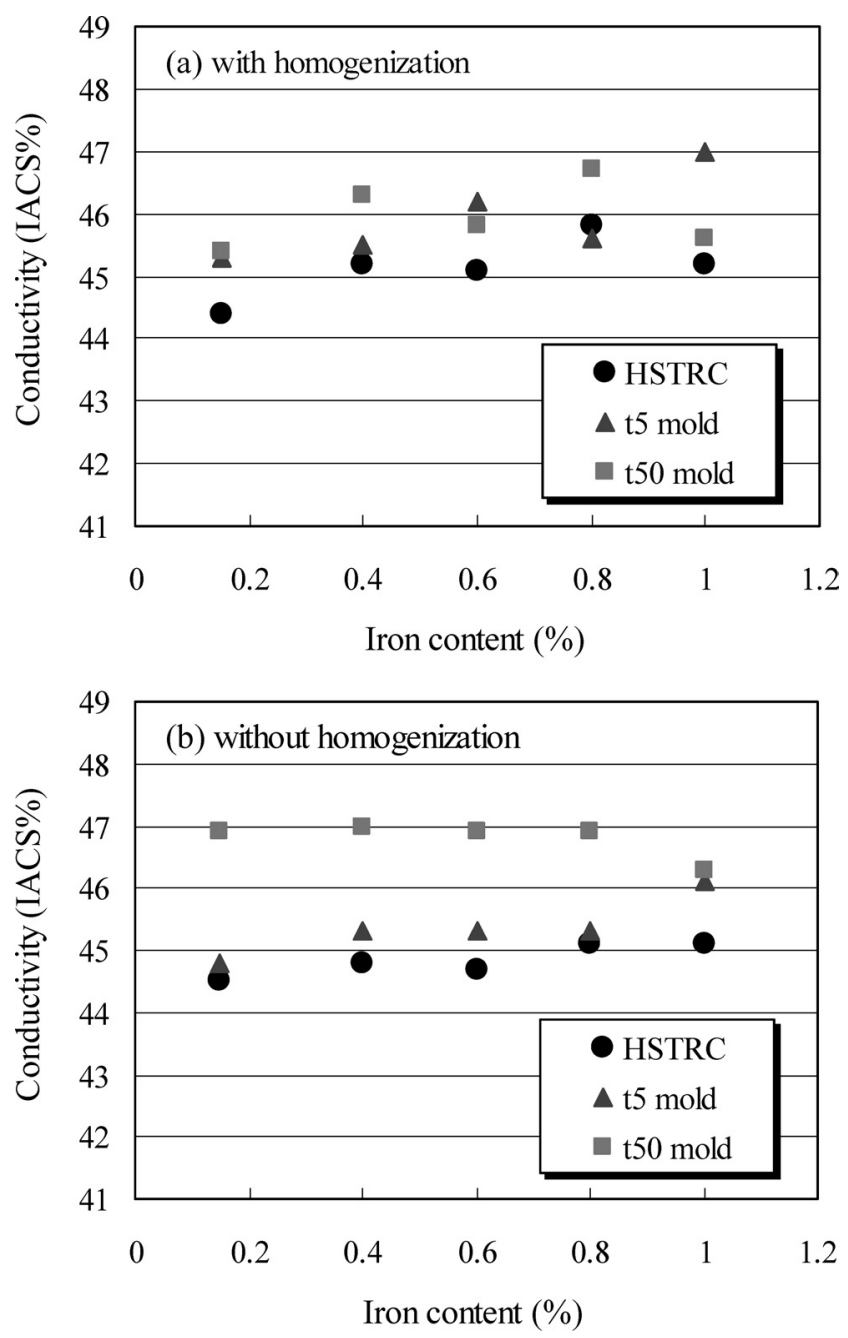

Fig. 9 Effect of iron content and cooling rate during solidification on conductivity for T4 sheets.

の導電率は $0.2 \% \mathrm{Fe}$ 材よりあ $5 \%$ 前後高くなるはずであり, $1 / 2$ 以下の増加量に留まっている。導電率上昇を抑制する原 因としては鉄量増加に伴う鉄, マンガン, マグネシウムなど の固溶量増加やクラスタの形成などが考えられる。固溶鉄量 と固溶マグネシゥム量については大きくは変化しないことを 確認しているが，現時点では原因の詳細は明らかになってい ない。

以上の結果より, 鉄含有量増加により固溶けい素量は低下

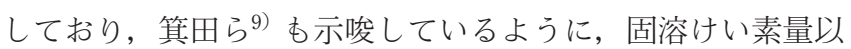

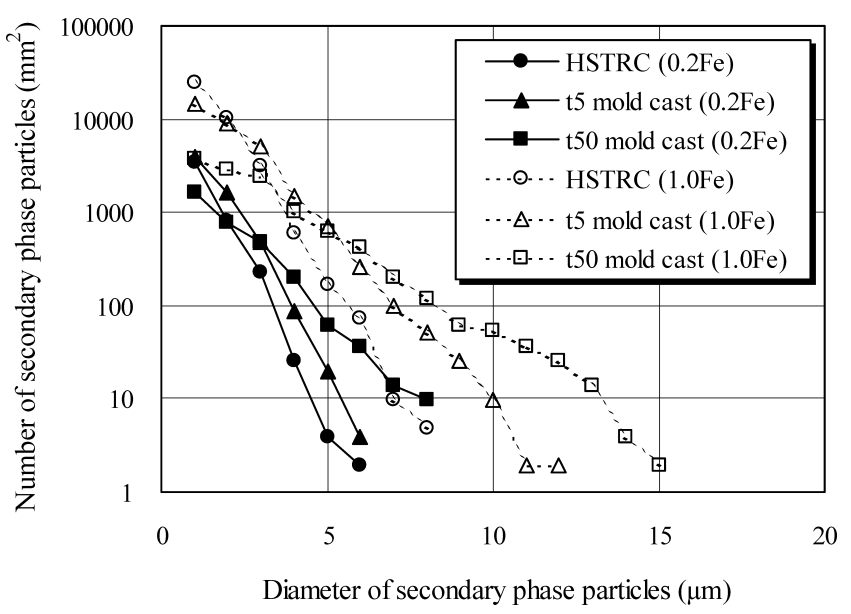

Fig. 10 Size distributions of secondary phase particles for T4 sheets.

外に $\mathrm{AB}$ 耐力上昇の要因があると考えられる。本研究では鉄 量を増加した場合は, 固溶けい素量減少による導電率上昇を 打ち消す因子があることを見出したが原因の詳細は明らかと なっておらず，今後の課題としたい。

b）引張特性に及ぼす凝固時の冷却速度の影響 凝固時の冷却速度が大きいほど溶質元素の固溶量が大き く, $\mathrm{T} 4$ 材, $\mathrm{AB}$ 材ともに強度が高いことが予想されたが，均 質化熱処理ありの工程では冷却速度の影響は小さかった。Fig. 9 より, 均質化熱処理ありの工程では, $\mathrm{T} 4$ 材の導電率は冷却 速度の影響をほとんど受けていない結果が得られており,こ れはいずれの冷却速度材も均質化熱処理時にほぼ一定の固溶 状態となったためと考えられる。一方, 均質化熱処理なしの 工程では t50 金型材の導電率が高く, t5 金型材, HSTRC 材の 順に低い值となっており, t5 金型材とHSTRC 材については 均質化熱処理ありの工程とほぼ同等の值であった。これは, 冷却速度の大きい急冷凝固材では均質化熱処理を省略しても 短時間の溶体化処理のみで溶質元素が十分に固溶しているこ とを示しており, $\mathrm{AB}$ 材の $0.2 \%$ 耐力の結果に対応したものと なっている。本結果より, 凝固時の冷却速度が大きい場合 は, 均質化熱処理工程の省略が可能であり, 更に, 高速双 ロールキャスト材では通常の双ロール材（本研究では t5 金型 材に相当）より高いベークハード性を得ることが可能である ことがわかった。

\section{2 曲げ性に及ぼす鉄量と凝固時の冷却速度の影響}

曲げ性に及ぼす鉄量の影響については従来から報告されて 
HSTRC

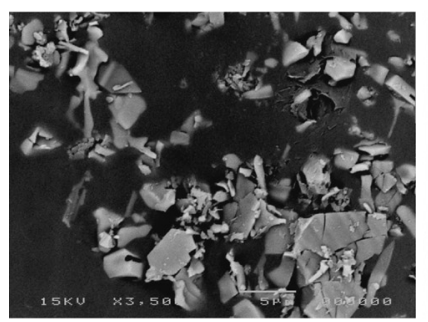

t5 mold cast

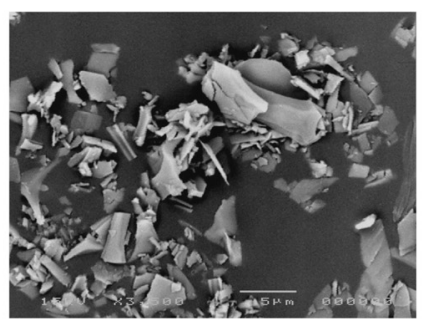

t50 mold cast

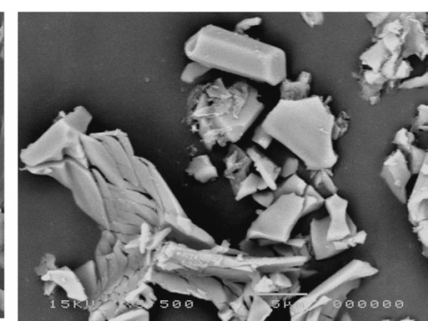

Fig. 11 SEM micrographs of extracted second phase particles from as-cast plate/ingot of 1.0\% Fe by the thermal phenol method.

いる結果 ${ }^{1)}$ と同様であり，鉄量の増加とともに曲げ性は低下 した。一方，凝固時の冷却速度の影響については，冷却速度 が大きいほど第 2 相粒子が微細化するために曲げ性が向上す ることが期待されたが，冷却速度の最も小さい 50 金型材で はやや曲げ性は低下したものの，HSTRC 材と $\mathrm{t} 5$ 金型材では ほぼ同等の曲げ性を示した。この結果を考察するために第 2 相粒子の粒度分布, 形態を調査した。Fig. 10 に $0.2 \% \mathrm{Fe}$ 材 と $1.0 \% \mathrm{Fe}$ 材の第 2 相粒子のサイズ分布調査結果, Fig. 11 に $1.0 \% \mathrm{Fe}$ 材の熱フェノール法により抽出した第 2 相粒子の SEM 観察結果を示す。Fig. 10 より, 全体的な傾向としては, 鉄量が多いほど，また凝固時の冷却速度が小さいほど粗大な

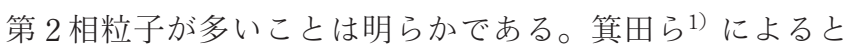
$2 \mu \mathrm{m}$ 以上の第 2 相粒子が割れの亀裂伝播経路となるため, 鉄 量の増加とともに粗大な第 2 相粒子が増加して曲げ性低下を 招くとされている。そこで, $2 \mu \mathrm{m}$ を超える第 2 相粒子数に着 目すると, $0.2 \% \mathrm{Fe}$ では HSTRC 材, $\mathrm{t} 5$ 金型材, $\mathrm{t} 50$ 金型材で それぞれ 250 個，590 個， 810 個 $/ \mathrm{mm}^{2}$ であるが， $1.0 \% \mathrm{Fe}$ では それぞれ 4000 個, 7800 個, 5000 個 $/ \mathrm{mm}^{2}$ までそれぞれ増加し ており, 凝固時の冷却速度による第 2 相粒子の微細化効果よ りあはるかに鉄量増加の影響が大きいことがわかる。また, 抽出した晶出物の観察結果 (Fig. 11) からも, HSTRC 材と t5 金型材では大きな差異はなく, $2 \mu \mathrm{m}$ 以上の第 2 相粒子は多く 存在することが確認できる。したがって, 冷却速度が $1000^{\circ} \mathrm{C} / \mathrm{s}$ を超える HSTRC 材であっても鉄量の増加に伴う曲げ 性低下の抑制は困難であったと考えられる。なお，鉄量が多 い組成では, $2 \mu \mathrm{m}$ 以上の粗大第 2 相粒子の数密度が最大で あった $\mathrm{t} 5$ 金型材よりも，冷却速度の最も小さい $\mathrm{t} 50$ 金型材の 曲げ性の低下が著しかったが，これは $10 \mu \mathrm{m}$ 前後の粗大な第 2 相粒子の影響であると思われる。

既述の通り，本研究で用いた HSTRC 材は鋳造割れ防止の ために冷却速度を抑えた条件で作製しており, 冷却速度 $1000^{\circ} \mathrm{C} / \mathrm{s}$ のオーダでは第 2 相粒子 (晶出物) の微細化が不十 分であり, 曲げ性改善の効果が得られなかったと考えられる。 今後は高速双ロールキャス夕本来の冷却能力（冷却速度 $6000^{\circ} \mathrm{C} / \mathrm{s}$ 程度）が得られる条件で健全な鋳造板を作製し，高 速双ロールキャストによる曲げ性改善の可能性を検討してい きたい。

なお, 曲げ性については, 第 2 相粒子以外にせん断帯形成 状態の影響1),9),11) や集合組織の影響11),12）が報告されている。 せん断帯形成については固溶状態の影響を受けるとされてい るが, 導電率などの結果より, 均質化熱処理ありの工程では 固溶状態に及ぼす冷却速度の影響は小さいため, せん断帯形 成状態は冷却速度では变化しないと考えられる。また，集合
組織については Cube 方位と Goss 方位の集積度（ランダム方 位に対する比率）はいずれの材料でもそれぞれ 1.6 2.1, 0.9 1.8 の範囲であり, 曲げ性には大きな影響は及ぼさない变 動範囲であると考えられる。

\section{5. 結言}

高速双ロールキャス夕を用い，6022 アルミニウム合金を ベースとした合金の機械的性質に及ぼす鉄量と凝固時の冷却 速度の影響を調査し，以下の結果が得られた。

（1） $\mathrm{T} 4$ 材と $\mathrm{AB}$ 材の $0.2 \%$ 耐力は鉄量の影響をほとんど受 けなかったが，伸びは鉄量の増加とともに低下した。

（2）凝固時の冷却速度が大きいほど $\mathrm{AB}$ 材の $0.2 \%$ 耐力は 高い傾向を示した。特に均質化熱処理なしの工程では冷却速 度が大きいほど顕著に高くなった。これは急冷凝固によって 固溶量が増加したためであると考えられた。

（3）曲げ性は鉄量の増加に伴い大幅に低下した。冷却速度 が遅い材料でその傾向は顕著であったが, 高速ロールキャス 卜材の曲げ性向上の効果は小さく, t5 金型材と同等であっ た。これは, 鉄量増加による粗大な第 2 相粒子の増加に対し て, 急冷凝固による第 2 相粒子の微細化が不十分であったた めと考えられる。

（4）高速双ロールキャスト材では, 均質化熱処理なしの工 程でも高いベークハード性が得られる可能性があることが分 かった。ただし, 曲げ性については高速双ロールキャスト材 の明確な優位性は確認されていない。更なる冷却速度向上に よる曲げ性改善の可能性検証は今後の課題としたい。

\section{参 考 文 献}

1）箕田 正, 内田秀俊, 渋江和久, 吉田英雄 : 軽金属, 53 (2003), 523-527.

2) J. Sarkar et al.: Materials Science and Engineering, A369 (2004), 258266.

3）崔 其, 大堀紘一, 齋藤 洋 : 軽金属, 48 (1998), 212-216.

4）渋江和久, 宇都秀之, 伊藤清文 : 軽金属学会第 107 回秋期大会 講演概要 (2004), 9-10.

5) T. Haga, K. Takahashi, M. Ikawa and H. Watari: J. Mater. Proc. Technol. 140 (2003), 610-615.

6) K. Suzuki, S. Kumai, Y. Saito and T. Haga: Mater. Trans. 46 (2005), 2602-2608.

7）徳田健二, 熊井真次, 鈴木健太, 宮崎 武, 石原暁子, 永田雄 介, 羽賀俊雄：軽金属, 57 (2007), 119-124.

8）軽金属学会編：研究部会報告書 No. 26, (1992), 154.

9）箕田 正，浅野峰生，吉田英雄：軽金属， 55 (2005)，222-226.

10）横田 稔, 佐藤謙一：軽金属, 32 (1982), 432-440.

11）浅野峰生, 伊川慎吾, 松田公一, 吉田英雄: 軽金属学会第 111 回秋期大会講演概要, (2006), 3-4.

12）日比野旭, 村松俊樹, 小松原俊雄, 佐賀 誠, 高田 健 : 軽金 属学会第 106 回春期大会講演概要，(2004)，89-90. 